\title{
PENERAPAN FUZZY MULTI ATTRIBUTE DECISION MAKING (FMADM) UNTUK PENENTUAN DESA/ KOTA LAYAK ANAK (KLA)
}

\author{
First Wanita ${ }^{1}$, Ramlah $\mathrm{P}^{2}$ \\ Teknik Komputer STMIK AKBA ${ }^{1}$, Sistem Informasi STMIK AKBA ${ }^{2}$ \\ Email: riri.fw@gmail.com, ramlah.akba@yahoo.co.id
}

\begin{abstract}
ABSTRAK
Penerapan Fuzzy Multi-Attribute Decision Making (FMADM) akan membantu memecahkan permasalahan atau fakta di lapangan yang selama ini dialami oleh para kepala desa dan jajaran terkait lainnya dalam pemenuhan kelayakan desa/kota layak anak. Sistem ini akan membantu para pemangku kepentingan mulai dari tingkat RT, RW, Desa/Kelurahan, Kecamatan hingga Kabupaten/Kota untuk mendapatkan berbagai macam terobosan , motivasi dan dorongan guna memenuhi persyaratan bagi wilayahnya sebagai Kota Layak Anak (KLA). Penelitian ini sebagai produk ilmu pengetahuan dan teknologi dalam bentuk model bagi pihak terkait dalam pemenuhan hak-hak anak terutama bagi kepala desa untuk menjadikan wilayahnya sebagai desa/kota layak anak. Penelitian ini juga diharapkan dapat memberikan manfaat sebagai konsultan atau instruktur dalam hal interpretasi, tahap pengorganisasian dan tahap pengaplikasian kepada pemerintahan desa bersama dengan kader tingkat desa dan seluruh stakeholders. Metode yang digunakan dalam penelitian Penerapan Fuzzy Multi-Attribute Decision Making (FMADM) untuk penentuan desa/kota layak anak (KLA) adalah metode R\&D (research and Development). Hal ini sesuai dengan tujuan penelitian untuk membangun model aplikasi teknologi informasi terpadu penerapan Fuzzy Multi-Attribute Decision Making (FMADM) untuk penentuan desa/kota layak anak (KLA), dan selanjutnya dilakukan pengujian terhadap kefektifan model/produk tersebut.
\end{abstract}

Kata Kunci: FMADM,Kota Layak anak, Research and Development

\section{ABSTRACT}

The application of Fuzzy Multi-Attribute Decision Making (FMADM) will help solve problems or facts in the field that have been experienced by village heads and other relevant ranks in fulfilling the feasibility of Kota Layak Anak. This system will help stakeholders from the RT, RW, Village / Village, Sub-District to Regency / City levels to get various kinds of breakthroughs, motivations and encouragement to meet the requirements for their region as Kota Layak Anak (KLA). This research as a product of science and technology in the form of a model for related parties in the fulfillment of children's rights, especially for the village head to make his area Kota Layak Anak. This research is also expected to provide benefits as a consultant or instructor in terms of interpretation, the stage of organizing and the stage of application to the village government together with village level cadres and all stakeholders. The method used in the study of the Application of Fuzzy Multi-Attribute Decision Making (FMADM) for the determination of Kota Layak Anak (KLA) is the $R \& D$ (research and 
development) method. This is in accordance with the purpose of the study to build an integrated information technology application model for the application of Fuzzy MultiAttribute Decision Making (FMADM) for the determination of Kota Layak Anak (KLA), and then to test the effectiveness of the model / product.

Keywords: FMADM, Kota Layak Anak, Research and Development

\section{Pendahuluan}

Semakin berkembangnya ilmu pengetahuan dan teknologi dengan pesat akan menginspirasi manusia menciptakan suatu hal yang baru. Salah satu contohnya dalam penggunaan teknologi komputer. Komputer yang biasanya hanya digunakan untuk mengolah data dan melakukan perhitungan matematika, saat ini sudah dapat dimanfaatkan sebagai pemberi solusi terhadap masalah yang diinputkan, seperti halnya sistem pendukung keputusan (SPK). Sistem pendukung keputusan dapat membantu pengambil keputusan untuk memecahkan masalah, terutama dalam berbagai isu yang sangat kompleks dan tidak terstruktur serta dapat menghasilkan solusi yang lebih cepat dan hasil yang lebih dapat diandalkan. Salah satu penggunaan SPK dalam analisis kelayakan penentuan Desa/Kota Layak Anak (KLA).

Kota Layak Anak (KLA) adalah kota yang mempunyai sistem pembangunan berbasis hak anak melalui pengintegrasian komitmen dan sumber daya pemerintah, masyarakat dan dunia usaha, yang terencana secara menyeluruh dan berkelanjutan dalam kebijakan, program dan kegiatan untuk menjamin terpenuhinya hak dan perlindungan anak. Tujuan KLA Secara umum pada tingkat bottom up (desa/kelurahan) untuk memenuhi dan melindungi anak dan secara khusus untuk membangun inisiatif pemerintahan desa yang mengarah pada upaya transformasi konversi hak anak dari kerangka hukum ke dalam defenisi, strategi dan intervensi pembangunan, dalam bentuk kebijakan, program dan kegiatan pembangunan yang ditujukan untuk pemenuhan hak dan perlindungan anak (PHPA) pada suatu wilayah desa.

Dalam melakukan pengembangan KLA sebagai upaya pemenuhan hak dan perlindungan anak para pemangku kepentingan harus menerapkan prinsip hak anak. Menuju pada pengalaman implementasi KLA selama ini pengembangan KLA dan perluasan wilayah percontohan KLA dapat dilakukan melalui pendekatan bottom up di mulai dari keluarga, gerakan masyarakat, meluas ke RT/RW ke Desa/Kelurahan dalam wujud "DESA/KELURAHAN LAYAK ANAK", selanjutnya meluas ke kecamatan dalam wujud "KECAMATAN LAYAK ANAK" dan berujung pada kabupaten/kota dalam wujud "KABUPATEN/KOTA LAYAK ANAK'.

\section{Kerangka Teori}

2.1 Multiple Criteria Decision Making (MCDM)

Multiple Criteria Decision Making (MCDM) adalah suatu metode pengambilan keputusan untuk menetapkan suatu alternatif terbaik dari sejumah alternatif berdasarkan beberapa kriteria tertentu. Kriteria biasanya berupa ukuran- 
ukuran, aturan-aturan atau standar yang digunakan dalam pengambilan keputusan. Berdasarkan tujuannya, MCDM dibagi menjadi 2 model yaitu Multiple Attribute Decision Making (MADM) dan Multiple Objektive Decision Making (MODM). MADM digunakan untuk menyelesaikan masalah-masalah dalam ruang diskret. MADM biasa digunakan untuk melakukan penilaian/seleksi terhadap beberapa alternatif dalam jumlah yang terbatas. Sedangkan MODM untuk menyelesaikan masalah pada ruang kontinyu (Kusumadewi, 2009).

\subsection{Multiple Attribute Decision Making (MADM)}

Proses MADM dilakukan melalui 3 tahap, yaitu penyusunan komponenkomponen situasi, analisis, dan sintesis informasi. Pada tahap penyusunan komponen situasi akan dibentuk tabel taksiran yang berisi identifikasi alternatif dan spesifikasi tujuan, kriteria dan atribut. Inti dari MADM adalah menentukan nilai bobot untuk setiap atribut, kemudian dilanjutkan dengan proses perankingan yang akan menyeleksi alternatif yang sudah diberikan. Pada dasarnya, ada 3 pendekatan untuk mencari nilai bobot atribut, yaitu pendekatan subyektif, pendekatan obyektif dan pendekatan integrasi antara subyektif dan obyektif. Masing-masing pendekatan memiliki kelebihan dan kelemahan. Pada pendekatan subyektif, nilai bobot ditentukan berdasarkan subyektifitas dari para pengambil keputusan, sehingga beberapa faktor dalam proses perankingan alternatif bisa ditentukan secara bebas. Sedangkan pada pendekatan obyektif, nilai bobot dihitung secara matematis sehingga mengabaikan subyektifitas dari pengambil keputusan (Zhang, 2014).

Beberapa metode yang dapat digunakan untuk menyelesaikan masalah MADM. antara lain :

a. Simple Additive Weighting Method (SAW);

b. Weighted Product (WP);

c. Elimination Et Choix Traduisant la Realite (ELECTRE);

d. Technique for Order Preference by Similarity to Ideal Solution (TOPSIS);

e. Analytic Hierarchy Process (AHP)

\subsection{Kota Kelayakan Anak (KLA)}

Kabupaten/Kota Layak Anak (KLA) adalah sistem pembangunan satu wilayah administrasi yang menintegrasikan komitmen dan sumberdaya pemerintah, masyarakat, dunia usaha yang terencana secara menyeluruh dan berkelanjutan dalam program kegiatan untuk menjamin pemenuhan hak dan perlindungan anak (Rumtianang, 2015).

Kabupaten/Kota adalah pembagian wilayah administrasi di Indonesia setelah provinsi yang dipimpin oleh seorang Bupati/Walikota. Dalam konteks peraturan ini, kabupaten/kota adalah pembagian wilayah administrasi dan geografi termasuk kecamatan, kelurahan/desa, rumah tangga dan keluarga (Dianto, 2015). Desa atau kota merupakan suatu hasil perwujudan geografis yang ditimbulkan oleh unsur-unsur fisografis, sosial, ekonomi, politk dan kultural yang terdapat pada suatu daerah serta memiliki hubungan dan pengaruh timbal balik dengan daeah lain (Dianto, 2015). Sedangkan menurut UU Desa, DESA adalah suatu wilayah yang ditempati oleh sejumlah penduduk, sebagai kesatuan masyarakat hukum yang mempunyai 
organisasi pemerintahan terendah langsung di bawah Camat dan mempunyai hak otonomi dalam ikatan negara kesatuan RI.

Layak diartikan dengan patut atau pantas, misalnya diperlakukan selayaknya. Layak yang dimaksud dalam kondisi fisik dan non fisik suatu wilayah dimana aspek kehidupannya memenuhi unsur-unsur yang diatur dalam Konvensi Hak Anak atau Undang-Undang Perlindungan Anak (Dianto, 2015).

Anak diartikan dengan keturunan kedua. Pengertian anak menurut pasal 1 ayat (1) Undang-Undang Republik Indonesia Nomor 35 Tahun 2014 Tentang Perubahan Atas Undang Undang-Undang Republik Indonesia Nomor 23 Tahun 2002 Tentang Perlindungan Anak, anak adalah seseorang yang belum berusia 18 (delapan belas) tahun, termasuk anak yang masih dalam kandungan.

KLA sangat penting diwujudkan agar anak tidak menjadi beban pembangunan, mengingat jumlah anak sekitar sepertiga dari total penduduk yang merupakan bagian yang tidak terpisahkan dari keberlangsungan hidup manusia dan keberlangsungann hidup bernegara. Alasan lain seperti kekerasan terhadap anak baik dilingkungan sekolah, lingkungan masyarakat dan lingkungan keluarga, lemahnya koordinasi dan kemitraan antar pemangku kepentingan terkait pemenuhan hak dan perlindungan anak, masih terbatasnya ruang bermain anak, belum semua pemangku kepentingan memahami hak anak, belum semua daerah mempunyai landasaan hukum untuk membangun anak, pembangunan kapasitas kelembagaan masih rendah, SDM, data, dan keterbatasan champions, serta peran pemerintah daerah yang belum optimal.
Indikator KLA merupakan variabel yang digunakan untuk mengukur pelaksanaan pemenuhan hak anak di daerah dalam upaya mewujudkan KLA dan merupakan acuan bagi pemerintah, pemerintah provinsi, dan pemerintah kabupaten/kota dalam perencanaan, pelaksanaan, pemantauan dan evaluasi kebijakan, program dan kegiatan pemenuhan hak anak untuk mewujudkan KLA. Indikator ini terdiri dari 6 indikator kelembagaan dan 25 indikator subtansi yang dikelompokkan dalam 5 klaster hak anak yaitu : Hak Sipil dan Kebebasan; Lingkungan Keluarga dan Pengasuhan Alternatif; Kesehatan dan Kesejahteraan Dasar; Pendidikan, pemanfaatan waktu luang dan kegiatan budaya; dan Perlindungan khusus

\section{Metodologi}

Metode yang digunakan dalam penelitian Penerapan Fuzzy Multiple Attribute Decision Making (FMADM) Untuk Penentuan Desa/Kota Layak Anak (KLA) adalah metode R\&D (research and Development). Hal ini sesuai dengan tujuan penelitian untuk membangun sebuah sistem berbasis teknologi informasi terpadu dengan menggunakan model fuzzy multiple attribute decision making (FMADM), dan selanjutnya dilakukan pengujian terhadap kefektifan produk aplikasi tersebut.

Tahapan penelitian mengacu pada langkah penelitian dan pengembangan, Brog \& Gall yang tersusun dalam beberapa tahapan, yaitu : 1) Tahap penelitian dan pengumpulan informasi, 2) Tahap perencanaan, 3) Tahap pengembangan produk, 4) Tahap uji coba, dan 5) Tahap perbaikan produk akhir. Langkah-langkah lebih jelasnya dapat dilihat pada gambar 1 


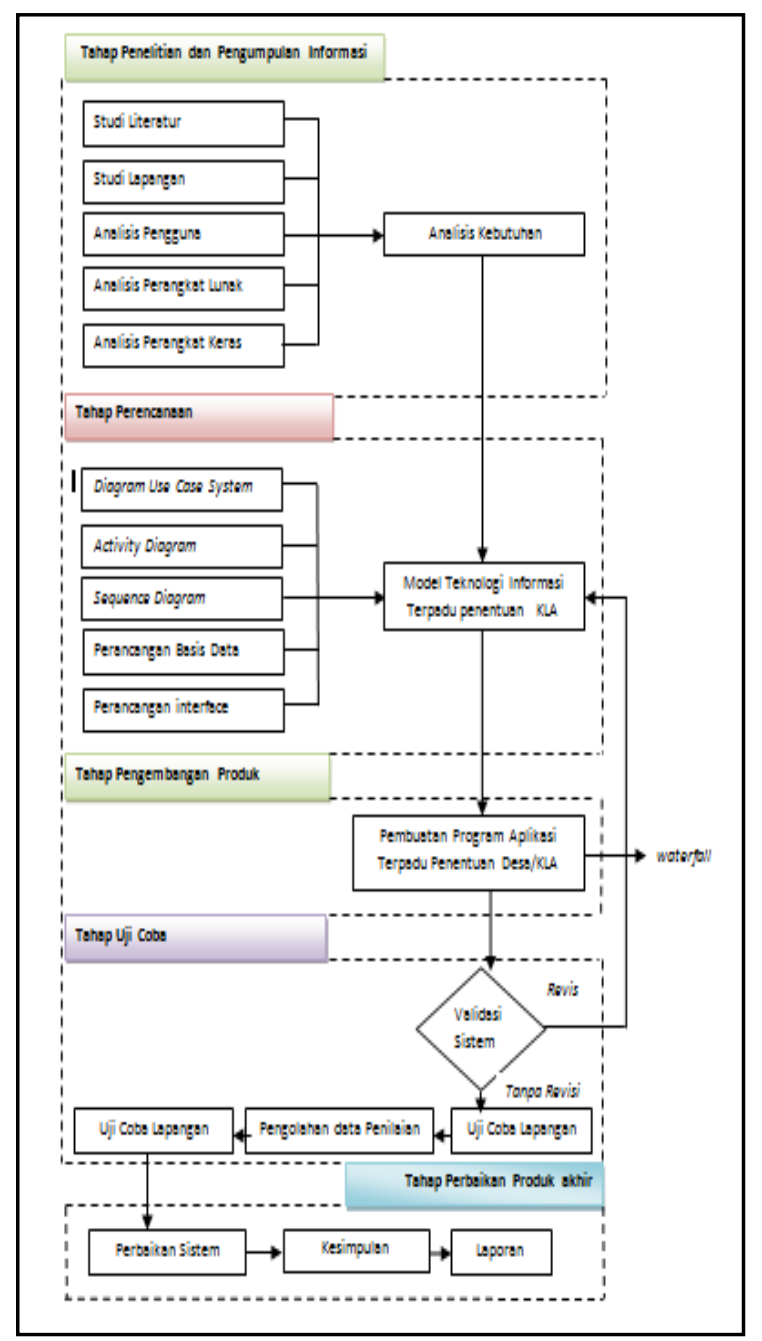

Gambar 1. Tahap Penelitian dan Pengembangan

\section{Implementasi dan Hasil}

Uji Coba Sistem dan Program

Pengujian sistem dilakukan untuk memeriksa kekompakan atau kinerja antar komponen Tujuan utama dari pengujian sistem adalah untuk memastikan bahwa elemen-elemen atau komponen-komponen dari sistem telah berfungsi sesuai yang diharapkan. Pengujian aplikasi akan dilakukan dengan teknik pengujian black box.

Proses perancangan ini merupakan tahap awal dari perancangan aplikasi penerapan Fuzzy Multi Attribute Decision Making (FMADM) Untuk Penentuan desa/kota layak anak yang dilakukan sebagai pemecahan masalah untuk mendapatkan suatu aplikasi yang memberikan solusi pada masalah yang terjadi

Diagram activity menggambarkan merupakan state diagram khusus, dimana sebagian besar state adalah action dan sebagian besar transisi di- trigger oleh selesainya state sebelumnya.

Pembahasan Listing Program atau Script yang digunakan sebagai berikut:

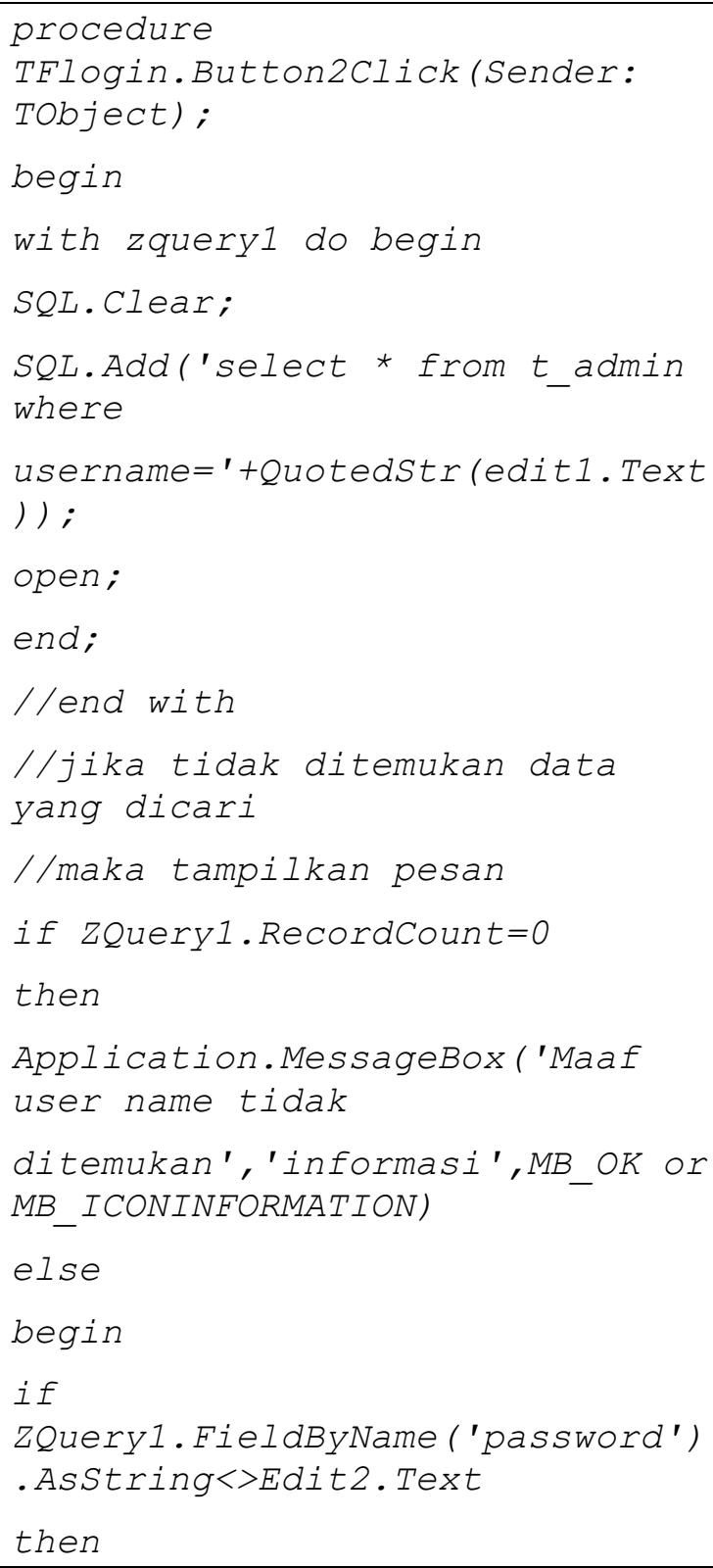


Application. MessageBox('past ikan password yang anda

masukkan

benar', 'error', MB OK Or

$M B$ ICONERROR)

else

begin

hide;

Fmenu. Show;

end;

end;

end;

Listing diatas merupakan listing untuk melakukan login ke sistem. Sebelum username dan password dieksekusi terlebih dahulu database pengguna dengan form login dikoneksikan seperti listing di atas. Setelah proses pengkoneksian database jika data sesuai maka login berhasil dan akan muncul tampilan utama dan jika login gagal maka akan muncul pesan error dari kesalahan login.

\section{Kesimpulan}

1. Rancang bangun sistem ini menggunakan Fuzzy Multi-Attribute Decision Making (FMADM), dan telah dilaksanakan penelitian pendahuluan, pembuatan desain hingga koding untuk penentuan desa/kota layak anak (KLA), sistem sudah diuji coba dan diimplementasikan pada desa.

2. Rancang bangun sistem ini jika telah selesai dan diharapkan dapat membantu pemangku kepentingan mulai dari tingkat RT, RW, Desa/Kelurahan, Kecamatan hingga Kabupaten/Kota untuk mendapatkan berbagai macam terobosan, motivasi dan dorongan guna memenuhi persyaratan bagi wilayahnya sebagai

Kota Layak Anak (KLA).

\section{Ucapan Terima kasih}

Penulis mengucapkan terima kasih kepada Direktorat Riset dan Teknologi Kemenristekdikti atas dukungan financial pada penelitian ini . Penulis juga berteima kasih kepada tim P3M STMIK AKBA atas diskusinya yang bermanfaat

\section{Daftar Pustaka}

[1]. Agus, Putu Eka Pratama. 2011. Sistem Informasi dan Implementasinya. Bandung: Penerbit Informatika

[2]. Dianto, Muhammad Erwin, 2015, Implementasi Program Kabupaten/Kota Layak Anak (KLA) di Desa Sendangtirto, Kecamatan Berbah, Kabupaten Sleman, Daerah Istimewa Yogyakarta, Skripsi UIN Sunan Kalijaga.

[3]. Fatoni, Kurniawan, 2015, Metode Fuzzy Multiple Attribute Decision Making (Fmadm) Sistem Penilaian Calon Penerima Manfaat, Jurnal Ilmiah MATRIK Vol.16 No.1, April 2014:45-58

[4]. Kementerian Pemberdayaan Perempuan dan Perlindungan Anak. 2015. Bahan Advokasi Kebijakan KLA. Jakarta; Kementerian PPPA Republik Indonesia.

[5]. Kusumadewi, Sri dkk. 2009. Fuzzy multi-Attribut Decision Making (Fuzzy MADM). Graha Ilmu. Yogyakarta.

[6]. Kusumadewi, Sri, Hari Purnomo. 2010. Aplikasi Logika FuzzyUntuk mendukung Keputusan.. Graha Ilmu. Yogyakarta.

[7]. Ladjamuddin, Al-Bahra Bin. 2013. Analsis dan Desain Sistem Informasi, Yogyakarta: Penerbit Graha Ilmu 
[8]. Peraturan Menteri Negara Pemberdayaan Perempuan Dan Perlindungan Anak Republik Indonesia Nomor 14 Tahun 2011 Tentang Panduan Evaluasi Kabupaten/Kota Layak Anak

[9]. Pressman, Roger S. 2013. Software Engineering A Practitioner's Approach Sixth Edition. New York: Mc Graw Hill Inc.

[10]. Rumtianang, Irma, 2014, Kota Layak Anak Dalam Perspektif Perlindungan Anak, Jurnal Pendidikan Pancasila dan Kewarganegaraan, Th. 27, Nomor 1, Pebruari 2014

[11]. Surya, Candra, 2015, Sistem Pendukung Keputusan Rekomendasi Penerima Beasiswa Menggunakan Fuzzy Multi Attribut Decision Making (FMADM) dan Simple Additive Weighting (SAW), Jurnal Rekayasa Elektrika, Volume 11 Nomor 4 Tahun 2015

[12]. Tedja, Jeanne Novaline, 2016, Studi Kebijakan Analisis Interpretasi Kebijakan KLA Di Tingkat Kota Serta Implementasi Di Lingkungan Rukun Warga (RW), Disertasi Promosi Doktor FISIP UI,

[13]. Undang-Undang Republik Indonesia Nomor 35 Tahun 2014 Tentang Perubahan Atas UndangUndang Nomor 23 Tahun 2002 Tentang Perlindungan Anak

[14]. Z. Zhang, U. Demsar, J. Rantala \& K. Virantaus, 2014, A fuzzy multiple-attribute decision-making modelling for vulnerability analysis on the basis of population information for disaster management, Journal International Journal of Geographical Information Science_ Volume 28, 2014 - $\underline{\text { Issue }}$ 